\title{
Analisis Kuadran Pengaruh Produk Domestik Regional Bruto Kabupaten/Kota Terhadap Pendaftar Jamaah Haji Sebelum dan Selama Pandemi Covid-19 Di Provinsi Kalimantan Tengah
}

\author{
M. Faishal Hadi D. ${ }^{1}$, Soemedi Hadiyanto ${ }^{2}$ \\ Kantor Wilayah Kementerian Agama Provinsi Kalimantan Tengah, Palangka Raya, \\ Indonesia $^{1}$ \\ Balai Latihan Tenaga Kesehatan Provinsi Papua, Jayapura, Indonesia ${ }^{2}$ \\ Corresponding authors: mfaishalhadi@gmail.com ${ }^{1}$, soemedihadiyanto@gmail.com ${ }^{2}$
}

\begin{abstract}
ABSTRAK
PSBB untuk mengantisipasi penyebaran virus Covid-19 menyebabkan laju pertumbuhan ekonomi melambat dan berakibat pada penurunan PDRB dan pendaftaran jamaah haji. Penelitian bertujuan mengkaji pengaruh PDRB kabupaten/kota terhadap pendaftar jamaah haji sebelum dan selama Pandemi Covid-19 di Provinsi Kalimantan Tengah. Metode penelitian kuantitatif dengan analisis korelasional. Variabel adalah PDRB atas harga berlaku dan jumlah pendaftar jamaah haji dari kabupaten/kota tahun 2017-2020. Pengujian statistik menggunakan Microsoft excel untuk analisis rasio, korelasi, regresi linear sederhana serta analisis kuadran. Hasil; pandemi Covid-19 telah menurunkan jumlah pendaftar jamaah haji sebesar $-33,52 \%$. Peningkatan PDRB di setiap kabupaten/kota cenderung meningkatkan jumlah pendaftar jamaah haji sebelum maupun selama Pandemi di tahun 2017-2019 dan 2020. PDRB telah mempengaruhi banyaknya pendaftar jamaah haji di tahun 2017 sebesar 86,83\%, tahun 2018 sebesar 84,25\%, tahun 2019 sebesar 87,00\% dan tahun 2020 sebesar 79,75\%. Jumlah pendaftar jamaah haji tinggi (sebelum dan sesudah pandemi Covid-19) di Kabupaten Kotawaringin Timur, Kota Waringin Barat, Kota Palangka Raya dan Kapuas sangat terpengaruh PDRB kabupaten/kota yang tinggi (kuadran 4), dan patut dijadikan sebagai best practice bagi kabupaten/kota lainnya.
\end{abstract}

Kata Kunci: Analisis kuadran, PDRB, Jamaah haji, Pandemi Covid-19.

\section{PENDAHULUAN}

Di awal tahun 2020, dunia dikejutkan dengan kasus pneumonia yang mudah menyebar keseluruh dunia dan merupakan strain virus corona baru. Kasus pertama kali di temukan di Wuhan China dan dikenal dengan Covid-19 (Yang et al., 2020). Organisasi Kesehatan Dunia (WHO) kemudian menetapkan Covid-19 tersebut sebagai pandemi secara global sejak 11 Maret 2020 (Dong et al., 2020). Covid-19 yang menyebabkan flu ringan hingga kematian, mempunyai masa inkubasi singkat sehingga mudah menyebar secara masif dan cepat (Kirigia dan Muthuri, 2020). Dampak penyebaran kasus yang tinggi di Indonesia tersebut kemudian dilakukan pembatasan sosial bersekala besar (PSBB) (Hadiwardoyo, 2020).

PSBB berdampak pada sektor ekonomi dan sosial (Hadiwardoyo, 2020), penghentian operasional berbagai sektor terkait perekonomian berdampak pada pertumbuhan ekonomi yang melambat (Halisa dan Annisa, 2020). Sektor ekonomi (economic sector) adalah kelompok besar bidang ekonomi dengan pengelompokan berdasarkan berbagai posisi pada rantai produksi, jenis pekerjaan produk atau layanan dan kepemilikan. Pertumbuhan ekonomi yang melambat merupakan multiplier effect akibat jumlah produksi barang domestik melambat sehingga berakibat penyerapan tenaga kerja melambat dan perekonomian daerah terganggu 
(Suseno dan Anas, 2017). Produk Domestik Regional Bruto (PDRB) adalah salah satu indikator ekonomi untuk mengukur kinerja pertumbuhan ekonomi daerah. PDRB merupakan kumulatif seluruh nilai tambah yang diciptakan berbagai sektor lapangan pekerjaan pada suatu tingkat wilayah tertentu, didasarkan pada PDRB atas dasar harga berlaku dan PDRB atas dasar konstan (Weley, Kumenaung dan Sumual, 2017).

PDRB diyakini sangat terkait dengan daya beli masyarakat (Fitriani, 2013) termasuk minat masyarakat untuk mendaftarkan diri sebagai jamaah haji. Pendaftaran jamaah haji untuk mendapatkan nomor porsi merupakan tahapan awal yang harus dilalui jamaah haji sebelum menunggu untuk diberangkatkan ke tanah suci, sehingga tercatatkan pada waiting list dalam sistem komputerisasi haji terpadu (Siskohat) (Yulianim, Sarbini dan Herman, 2016), Haji merupakan rukun Islam kelima. Menunaikan ibadah haji merupakan ritual tahunan yang dilakukan kaum muslim yang mampu secara fisik, ilmu dan material untuk berkunjung ke beberapa lokasi di Arab Saudi dengan melaksanakan beberapa aktifitas di bulan Dzulhijjah. Syarat wajib seorang muslim berhaji adalah Islam, berakal, baligh, merdeka dan mampu berupa bekal dan biaya perjalanan (Sahil, 2015). Kewajiban berhaji setiap muslim inilah yang mendorong untuk mendaftar jamaah haji yang tentunya sangat tergantung pada kondisi perekonomiannya untuk memenuhi bekal dan biaya perjalanan. PSBB yang mempengaruhi sektor perekonomian berdampak pada pendaftaran jamaah haji oleh masyarakat.

Permasalahan terkait dengan pengaruh PDRB kabupaten/kota terhadap pendaftar jamaah haji sebelum dan selama Pandemi Covid-19 belum pernah dilakukan penelitian di Kalimantan Tengah. Penelitian Romhadhoni, Faizah dan Afifah (2018) di Jakarta hanya membahas PDRB berdasarkan variabel pertumbuhan ekonomi dan tingkat pengangguran terbuka sedangkan penelitian Zasriati, Hayuni dan Wahyuni (2020) di Kabupaten Kerinci Provinsi Jambi hanya membahas tingkat pertumbuhan ekonomi dan potensi ekonomi terhadap PDRB.

Pertanyaan penelitian ini adalah apakah terdapat pengaruh PDRB kabupaten/kota terhadap pendaftar jamaah haji sebelum dan selama Pandemi Covid-19? Penelitian bertujuan mengkaji pengaruh PDRB kabupaten/kota terhadap pendaftar jamaah haji sebelum dan selama Pandemi Covid-19 di Provinsi Kalimantan Tengah. Hasil penelitian ini diharapkan dapat menjadi acuan dalam perencanaan peningkatan pendaftar jamaah haji dan bahan penyusunan perencanaan peningkatan PDRB kabupaten/kota pada masa pandemi Covid-19 di Provinsi Kalimantan Tengah.

\section{METODE PENELITIAN}

Penelitian dengan pendekatan kuantitatif menggunakan metode statistik inferensial atau induktif berupa analisis korelasional. Metode statistik inferensial berfungsi untuk melakukan analisis agar dapat dilakukan penarikan kesimpulan dan pengambilan keputusan. Variabel yang diteliti adalah PDRB atas harga berlaku dan jumlah pendaftar jamaah haji dari 14 kabupaten/kota di Provinsi Kalimantan Tengah. Data diperoleh dari data PDRB kabupaten/Kota di Indonesia tahun 2017-2019 yang dirilis oleh https://bps.go.id/ (Badan Pusat Statistik, 2020) dan jumlah pendaftar jamaah haji di 14 kabupaten/kota dari Sistem Komputerisasi Haji Terpadu (SISKOHAT) pada Bidang Penyelenggaraan Haji dan Umrah Kantor Wilayah Kementerian Agama Provinsi Kalimantan Tengah tahun 2017-2020.

Penelitian ini bertujuan untuk menjawab pertanyaan penelitian yaitu apakah terdapat pengaruh PDRB kabupaten/kota terhadap pendaftar jamaah haji sebelum dan selama Pandemi Covid-19 di Provinsi Kalimantan Tengah?. Pengujian statistik menggunakan Microsoft excel untuk analisis rasio, korelasi, regresi linear sederhana serta analisis kuadran. Analisis rasio dan 
korelasi digunakan untuk mengetahui seberapa besar dan kuat hubungan antar variabel yang diuji, sedangkan untuk mengetahui perkiraan persamaan jumlah pendaftar jamaah haji dan PDRB serta besaran signifikansi variabel digunakan analisis regresi. Kuadran analisis digunakan untuk mengklasifikasi pada sampel mana saja pengaruh variabel yang diuji berpengaruh besar. Kuadran analisis merupakan teknik analisis untuk mengidentifikasikan faktor-faktor kinerja penting yang harus ditunjukkan. Kuadran analisis atau Importance Performance Analysis (IPA) ditemukan John A. Martilla dan John C. James tahun 1977 (Suhendra dan Prasetyanto, 2016).

\section{HASIL DAN PEMBAHASAN}

\section{Trend Pendaftar Jamaah Haji Tahun 2017-2020}

Jumlah pendaftar calon jemaah haji di Provinsi Kalimantan Tengah memiliki kecenderungan meningkat dari 4.146 orang di tahun 2017, menjadi 5.058 orang tahun 2018 dan 5.387 orang pada tahun 2019 (peningkatan setara 29,93\% per tahun). Rerata jumlah pendaftar jamaah haji provinsi meningkat dari 296 orang di tahun 2017 menjadi 385 orang tahun 2019, sedangkan rerata tahun 2020 cenderung menurun yaitu 244 orang (penurunan setara $36,55 \%$ dari tahun 2019). Kota Palangka Raya merupakan kabupaten dengan jumlah pendaftar jamaah haji tertinggi dengan 934 orang tahun 2019 atau rerata 735 orang per tahun selama periode tahun 2017-2019. Kabupaten Kapuas berada pada urutan kedua jumlah pendaftar jamaah haji dengan 842 orang, kemudian Kotawaringin Timur dengan 762 orang, Kotawaringin Barat dengan 661 orang, Barito Selatan dengan 406 orang dan Barito Utara dengan 452 orang. Keenam kabupaten/kota tersebut berada di atas rerata pendaftar calon jemaah haji yaitu 385 orang, sedangkan 8 kabupaten/kota lainnya berada di bawah rerata yaitu Murung Raya, Seruyan, Barito Timur, Katingan, Pulang Pisau, Lamandau, Sukamara dan terendah di Gunung Mas.

Gambar 1. Trend Pendaftar Jamaah Haji Provinsi Kalimantan Tengah Tahun 2017-2019

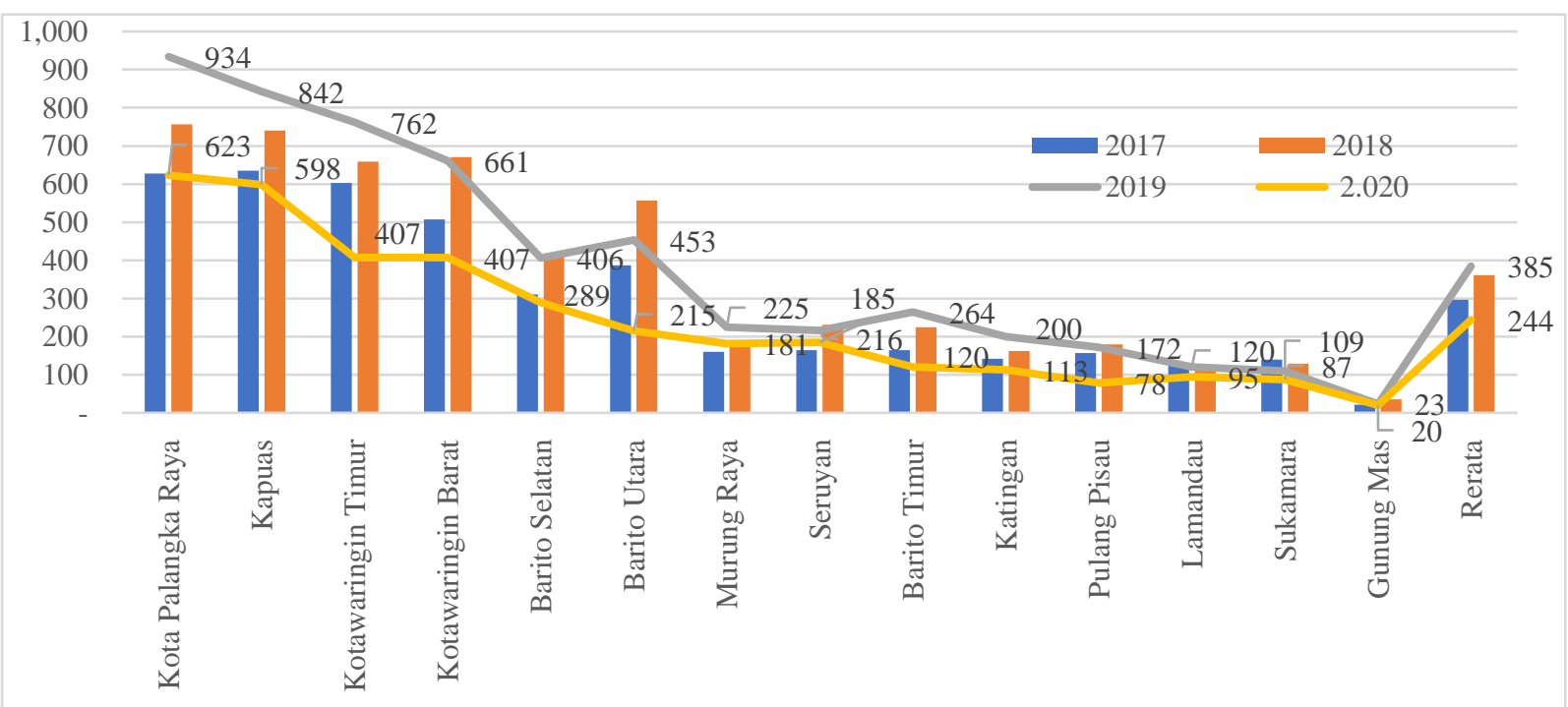

Sumber: Data Sekunder diolah, 2021.

Rerata jumlah pendaftar jamaah haji sebelum era Pandemi Covid-19 di tahun 2017-2019 adalah 347 orang dengan persentasi perkembangan pendaftar sebesar 25,09\%. Tertinggi di Kota Palangka Raya dengan 773 orang, kemudian Kapuas dengan 739 orang, Kotawaringin Timur dengan 675 orang, Kotawaringn Barat dengan 613 orang, Barito Utara dengan 466 orang 
dan Barito Selatan 377 orang. Keenam kabupaten/kota tersebut berada diatas rerata, sedangkan 8 kabupaetn/kota lainnya berada di bawah rerata yaitu Murung Raya, Katingan, Barito Timur, Seruyan, Lamandau, Pulang Pisau, Sukamara dan terendah di Gunung Mas dengan hanya 26 orang. Persentase perkembangan pendaftar jamaah haji tertinggi adalah Kabupaten Barito Timur dengan 60,98\%\%, kemudian Kota Palangka Raya dengan 48,73\%, Murung Raya dengan 40,63\%, Katingan dengan 40,85\%, Kapuas dengan 32,60\%, Seruyan dengan 31,71\%, Barito Selatan dengan 30,55\%, Kotawaringin Barat dengan 30,37\% dan Kotawaringin Timur dengan 26,37\%. Ke Sembilan kabupaten/kota tersebut berada diatas rerata, sedangkan yang di bawah rerata adalah Barito Utara, Pulang Pisau, Gunung Mas dan terendah Kabupaten Lamandau dengan 5,51\%.

Gambar 2. Trend Rerata Pendaftar dan Persentase Perkembangan Pendaftar Jamaah Haji Provinsi Kalimantan Tengah Tahun 2017-2019

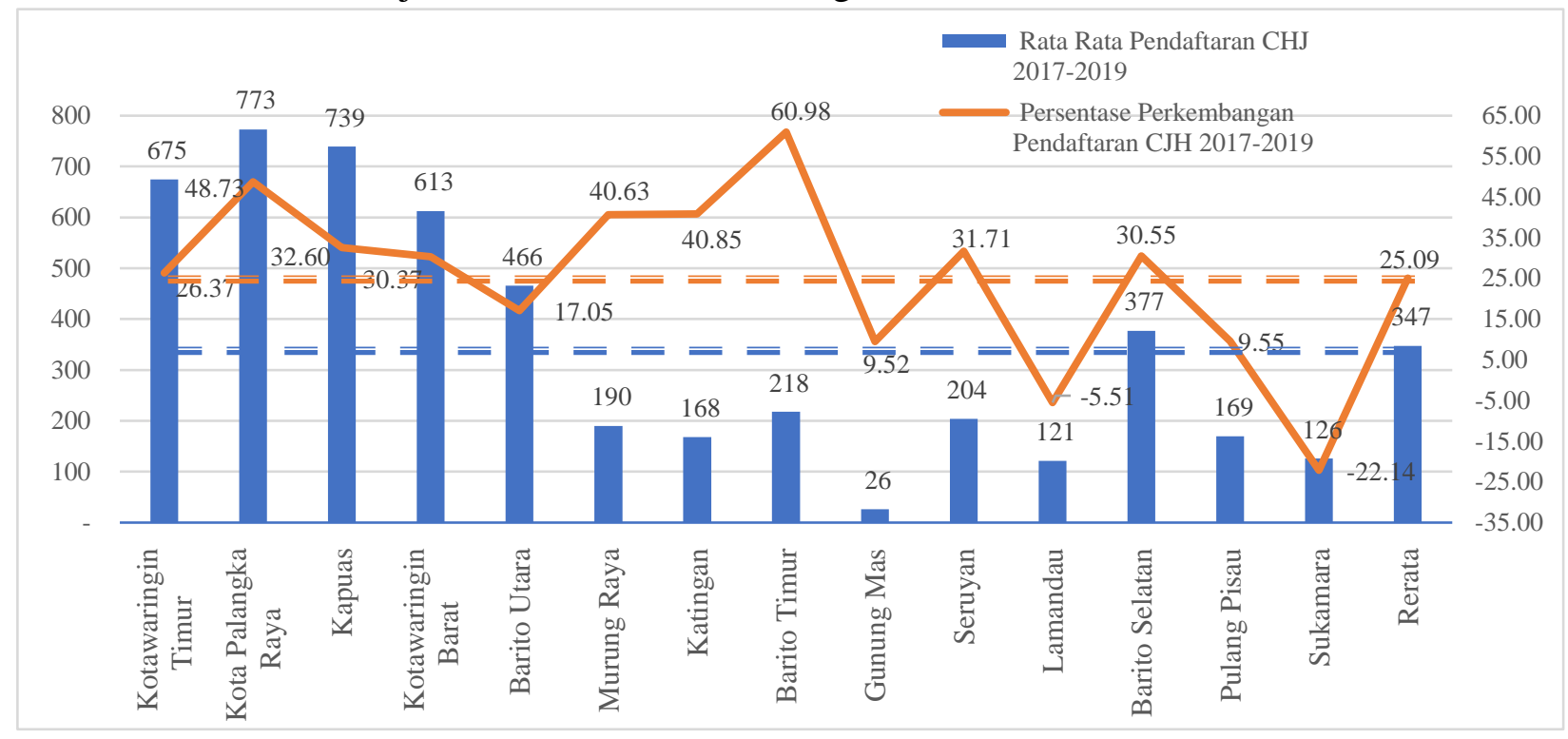

Sumber: Data Sekunder diolah, 2021.

Rerata jumlah pendaftar jamaah haji di Era Pandemi Covid-19 tahun 2020 hanya 244 orang atau menurun sebesar $-33,52 \%$ dibandingkan tahun 2019. Tertinggi di Kota Palangka Raya dengan 623 orang, kemudian Kapuas dengan 598 orang, Kotawaringin Timur dan Kotawaringin Barat masing-masing dengan 407 orang, Barito Selatan dengan 289 orang. Kelima Kabupaten/kota tersebut berada diatas rerata 244 orang, sedangkan kabupaten/kota lainnya berada di bawah rerata yaitu Barito Utara, Murung Raya, Seruyan, Barito Timur, Katingan, Pulang Pisau, Lamandau, Sukamara dan terendah di Gunung Mas. Kabupaten dengan persentase penurunan pendaftar jamaah haji terendah adalah Kabupaten Pulang Pisau dengan $-54,55 \%$, Barito Timur dengan $-55,65 \%$, Barito Utara dengan -52,54\%, Kotawaringin Timur dengan 46,59\%, Katingan dengan 43,50\% dan Kotawaringin Barat dengan 38,43\%. Ke enam kabupaten/kota tersebut berada diatas rerata, sedangkan 8 kabupaten/kota lainnya berada di bawah rerata yaitu Kota Palangka Raya, Barito Selatan, Kapuas, Lamandau, Sukamara, Murung Raya, Seruyan dan terendah adalah Kabupaten Gunung Mas dengan 13,04\%. Data diatas menunjukkan temuan penting bahwa pandemi Covid-19 telah mempengaruhi rerata jumlah pendaftar jamaah haji sebelum era Pandemi Covid-19 di tahun 2017-2019 yaitu 347 orang dan selama Era Pandemi Covid-19 tahun 2020 hanya 244 orang atau menurun sebesar $33,52 \%$. 
Gambar 3. Trend Pendaftar dan Persentase Perkembangan Pendaftar Jamaah Haji Provinsi Kalimantan Tengah Tahun 2019-2020

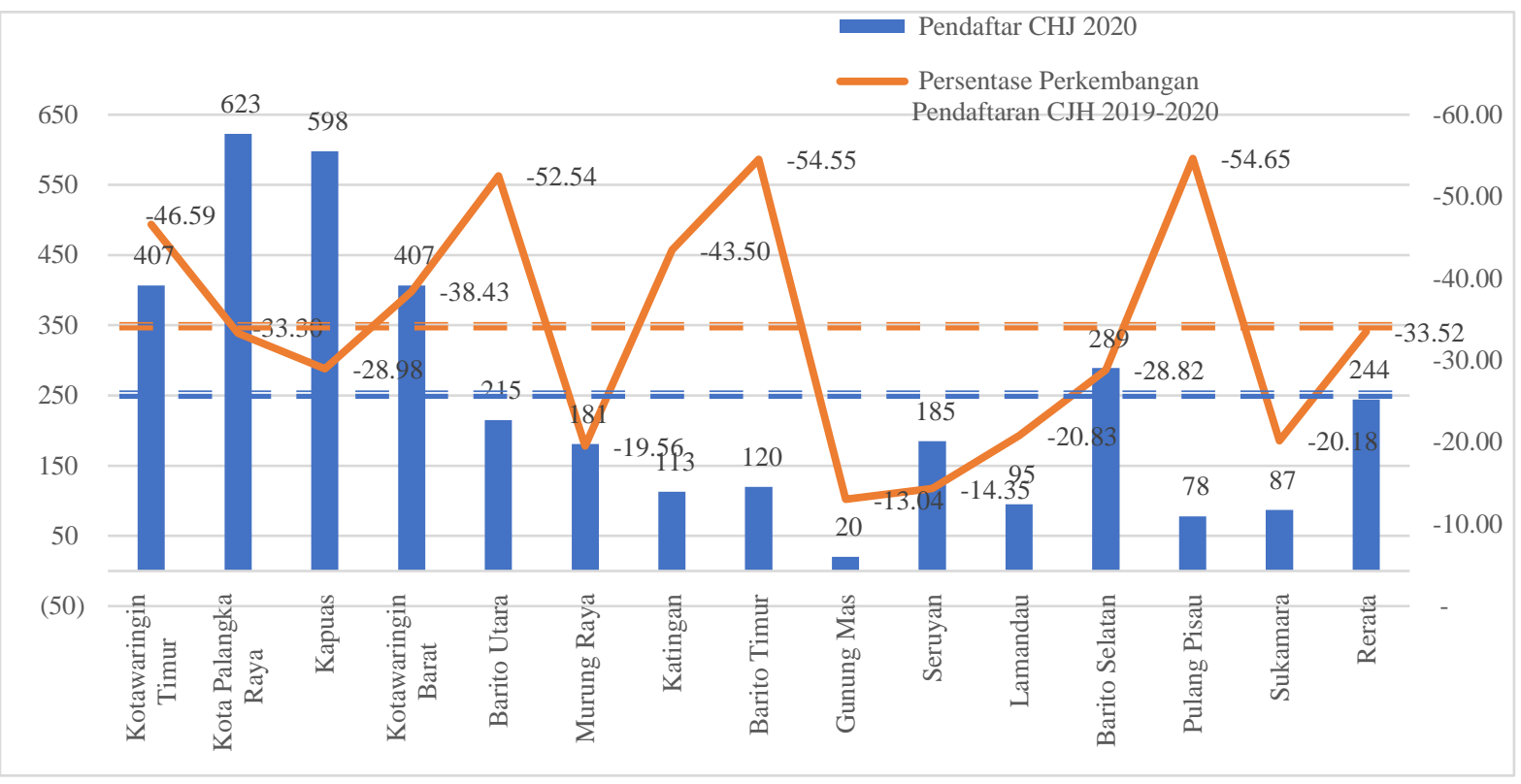

Sumber: Data Sekunder diolah, 2021.

\section{Trend PDRB atas dasar harga berlaku per Kabupaten/kota}

Gambar 4. Trend PDRB Provinsi Kalimantan Tengah Tahun 2017-2019

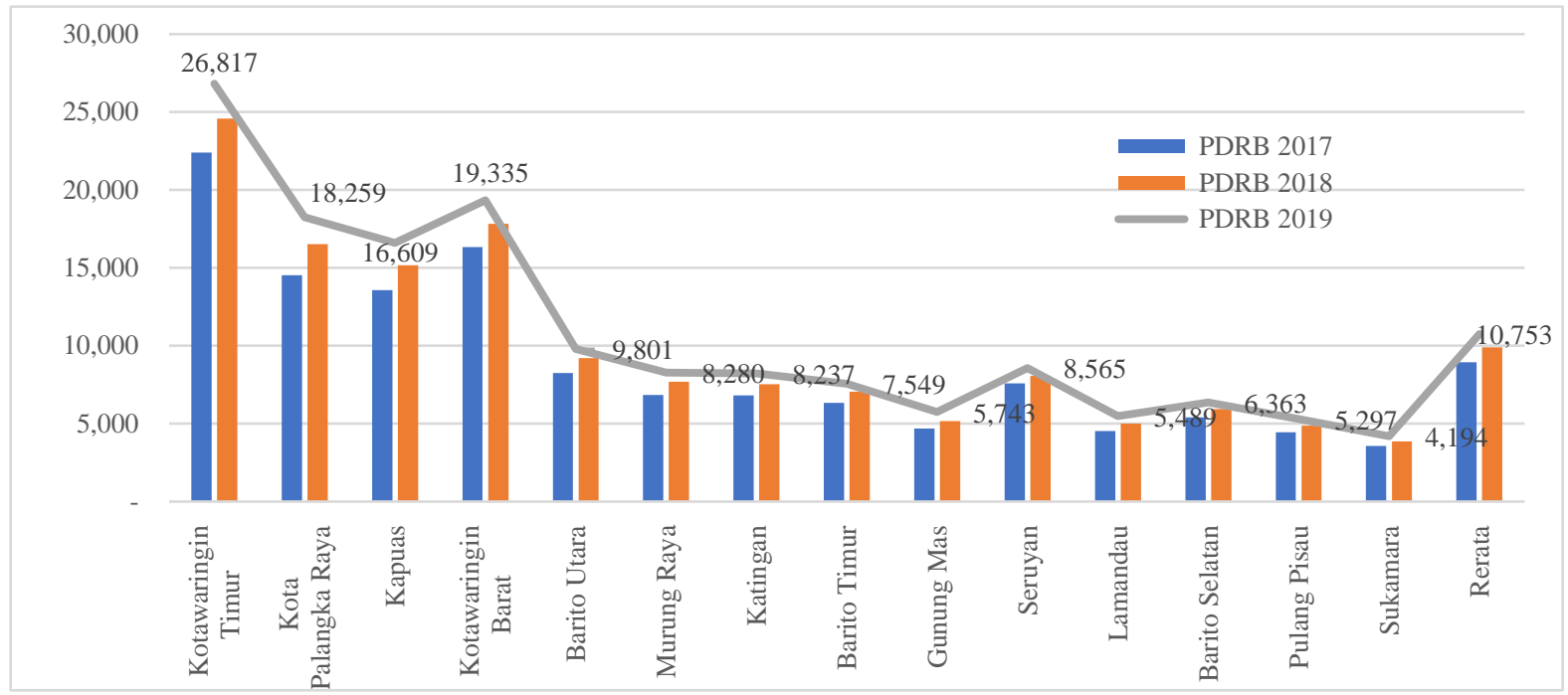

Sumber: Data Sekunder diolah, 2021.

PDRB atas dasar harga se Kalimantan Tengah selama tahun 2017-2019 dengan rerata 9.864 Milyar, memiliki kecenderungan meningkat, rerata tahun 2017 sebesar 8.948 Milyar, kemudian tahun 2018 sebesar 9.993 Milyar dan tahun 2019 sebesar 10.753 Milyar. Rerata PDRB tertinggi adalah Kabupaten Kotawaringin Timur dengan 24.591 Milyar, kemudian Kotawaringin Barat dengan 18.835 Milyar, Kota Palangka Raya dengan 18.259 Milyar dan Kapuas dengan 15.112 Milyar. Keempat kabupaten/kota tersebut merupakan kabupaten/kota dengan indeks PDRB diatas rerata, sedangkan 10 kabupaten/kota lainnya berada di bawah 
rerata yaitu kabupaten Barito Utara, Murung Raya, Katingan, Barito Timur, Gunung Mas, Lamandau, Barito Selatan, Pulang Pisau dan Sukamara dengan PDRB terendah yaitu 3.883 Milyar. Trend PDRB terus meningkat sejak tahun 2017, angka tertinggi di tahun 2019 dengan Kabupaten Kotawaringin Timur merupakan yang tertinggi dengan 26.817 Milyar, kemudian Kotawaringin Barat dengan 19.335 Milyar, Kota Palangka Raya dengan 18.259 Milyar dan Kapuas dengan 16.609 Milyar. Keempat kabupaten/kota tersebut merupakan kabupaten/kota dengan indeks PDRB diatas rerata, sedangkan 10 kabupaten/kota lainnya berada di bawah rerata yaitu kabupaten Barito Utara, Murung Raya, Katingan, Barito Timur, Gunung Mas, Lamandau, Barito Selatan, Pulang Pisau dan Sukamara dengan PDRB terendah yaitu 5.297 Milyar.

Gambar 5. Trend Rerata dan Persentase Perkembangan PDRB Provinsi Kalimantan Tengah Tahun 2017-2019

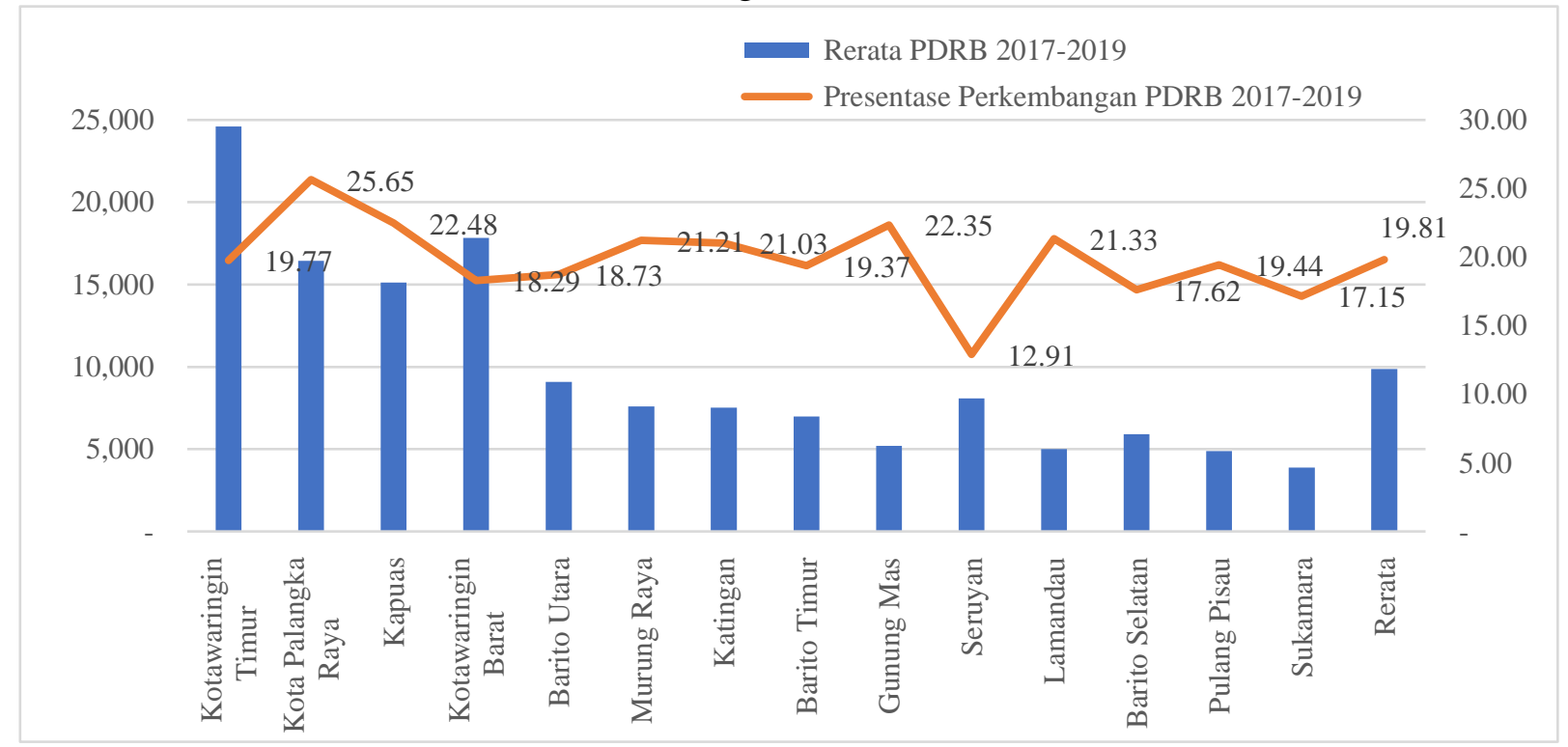

Sumber: Data Sekunder diolah, 2021.

Perkembangan PDRB atas dasar harga berlaku se Kalimantan Tengah selama 2017-2019 mengalami kenaikan secara rata rata sebesar 19,81\%. Kota Palangka Raya merupakan kabupaten/kota dengan perkembangan tertinggi sebesar 25,65\%, kemudian Kabupaten Kapuas 22,48, Gunung Mas dengan 22,35\%, Lamandau 21,33\%, Katingan dengan 21,03\% dan Murung Raya dengan $21,21 \%$. Ke enam kabupaten/kota tersebut berada diatas rerata, sedangkan 8 kabupaten/kota lainnya berada di bawah rerata yaitu Kotawaringin Timur, Kotawaringin Barat, Barito Utara, Barito Timur, Barito Selatan, Pulang Pisau, Sukamara dan terendah adalah Kabupaten Seruyan dengan 12,91\%.

Uji Korelasi Regresi Pengaruh PDRB terhadap Pendaftar Jamaah Haji Kabupaten/Kota Data PDRB atas dasar harga se Kalimantan Tengah selama tahun 2017-2019 dengan rerata 9.864 Milyar apabila disandingkan dengan rerata jumlah pendaftar jamaah haji sebelum era Pandemi Covid-19 di tahun 2017-2019 adalah 347 orang, memiliki kecenderungan hubungan yang erat. Trend angka rerata PDRB kabupaten/kota juga diikuti oleh angka rerata pendaftar jamaah haji. Temuan penting ini menunjukkan bahwa setiap peningkatan angka PDRB di setiap kabupaten/kota Provinsi Kalimantan Tengah mempunyai kecenderungan peningkatan jumlah pendaftar jamaah haji sebelum era Pandemi Covid-19 di tahun 2017-2019. Hal ini sesuai pernyataan Halisa dan Annisa (2020) bahwa PDRB terkait dengan berbagai sektor ekonomi. 
Gambar 6. Trend Rerata PDRB dan Jumlah Perkembangan Jamaah Haji Provinsi Kalimantan Tengah Tahun 2017-2019

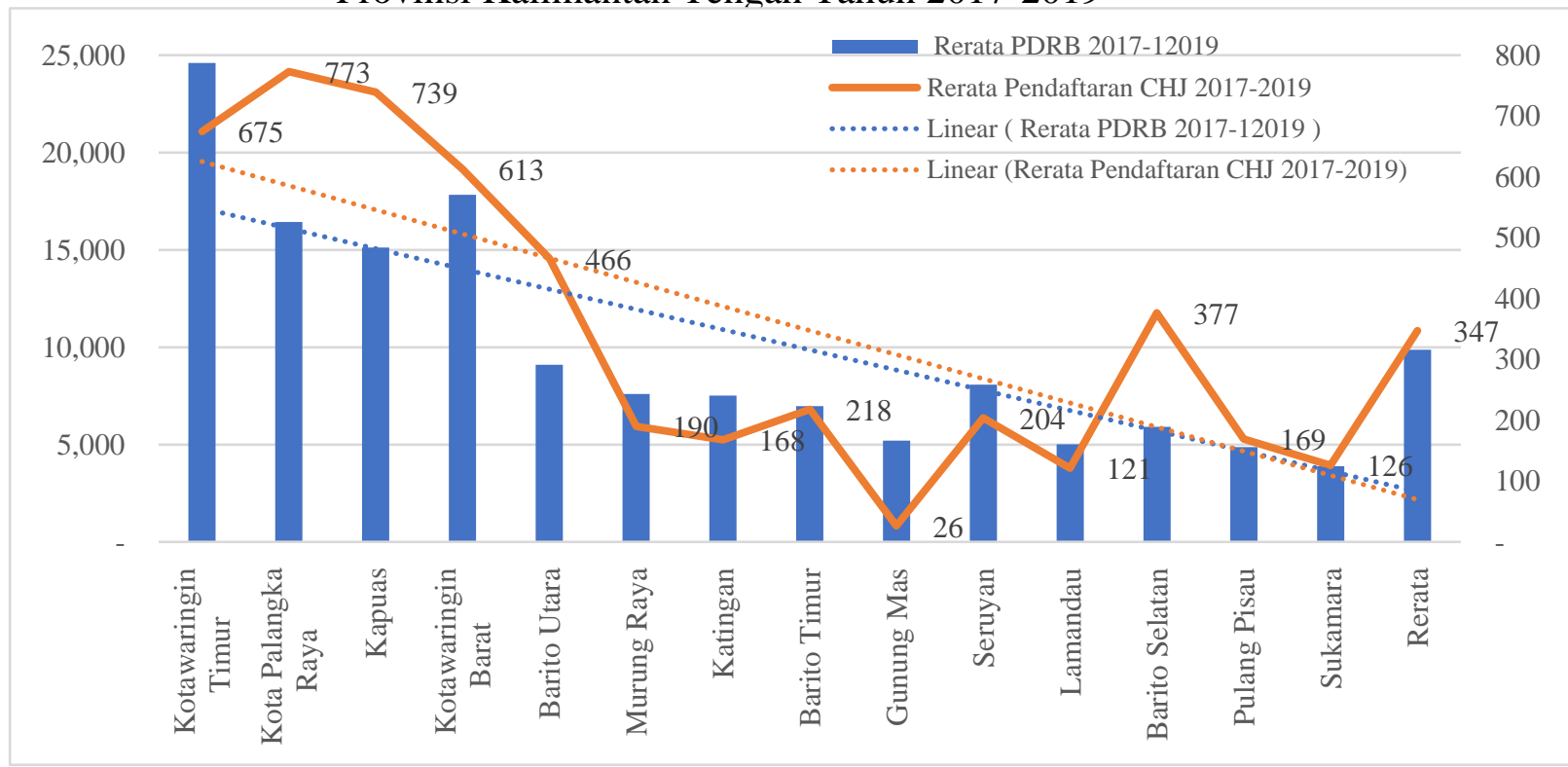

Sumber: Data Sekunder diolah, 2021.

Gambar 7. Trend Rerata PDRB 2017-2019 dan Jumlah Perkembangan Jamaah Haji Provinsi Kalimantan Tengah Tahun 2020

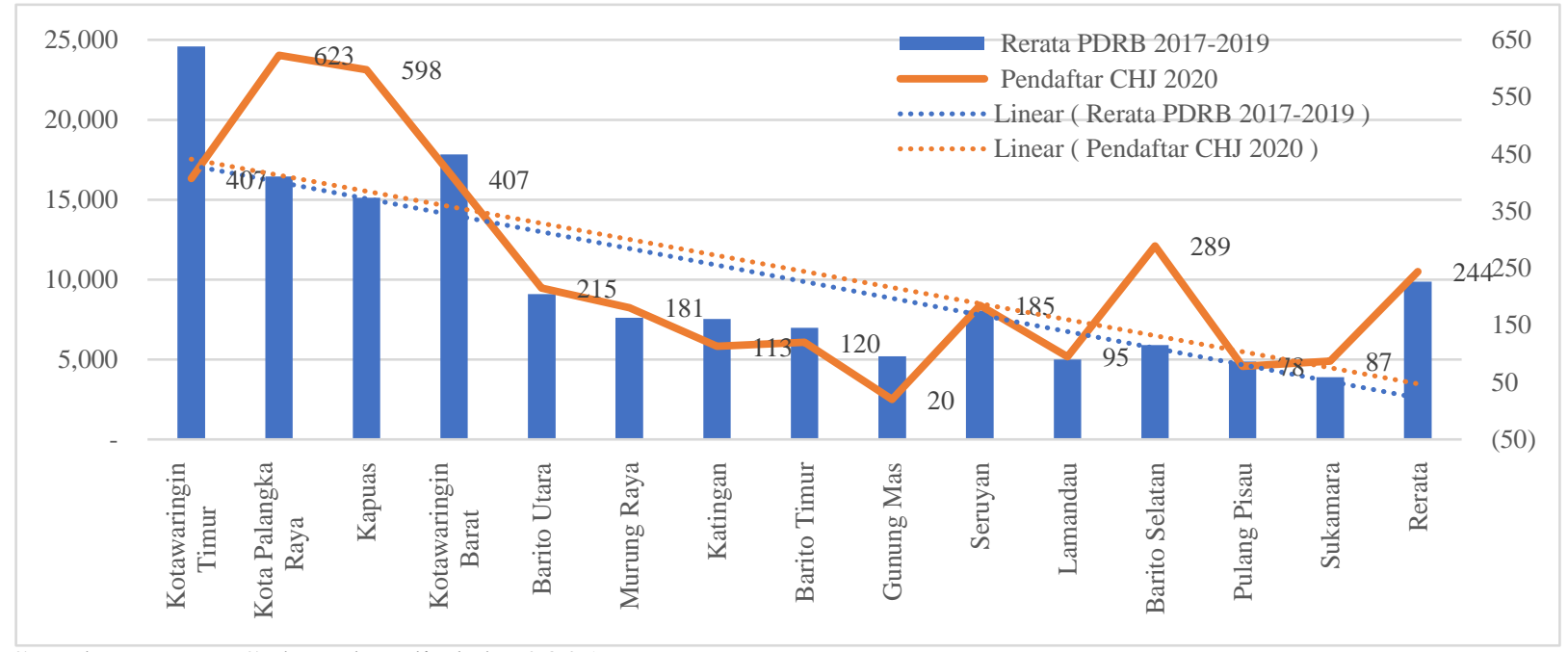

Sumber: Data Sekunder diolah, 2021.

Data PDRB atas dasar harga se Kalimantan Tengah selama tahun 2017-2019 dengan rerata 9.864 Milyar (penggunaan angka rerata PDRB 2017-2019 karena angka PDRB 2020 diasumsikan stagnan) apabila disandingkan dengan rerata jumlah pendaftar jamaah haji di Era Pandemi Covid-19 tahun 2020 hanya 244 orang atau menurun sebesar $-33,52 \%$, juga memiliki kecenderungan yang erat. Trend angka rerata PDRB kabupaten/kota juga diikuti oleh angka rerata pendaftar jamaah haji. Temuan penting ini menunjukkan bahwa setiap peningkatan angka PDRB di setiap kabupaten/kota Provinsi Kalimantan Tengah mempunyai kecenderungan peningkatan jumlah pendaftar jamaah haji selama era Pandemi Covid-19 di tahun 2020. Walaupun jumlah pendaftar jamaah haji menurun selama tahun 2020 tetapi trendnya tetap terkait dengan angka PDRB artinya PDRB tetap terkait dengan jumlah 
pendaftar jamaah haji dengan titik keseimbangan tertentu sesuai dengan trend angka PDRB tiap kabupaten/kota.

Analisis ratio menunjukkan bahwa pola pertumbuhan PDRB tahun 2018 sebesar 1,11 menurun di tahun 2019 sebesar 1,09, hal ini terjadi di semua kabupaten/kota kecuali Kabupaten Gunung Mas yang rasionya meningkat. Pola pertumbuhan jamaah haji tahun 2018 sebesar 1,22 menurun di tahin 2019 sebesar 1,07 dan sangat menurun di era pandemi Covid-19 di tahun 2020 sebesar 0,63, penurunan yang drastis terjadi di Kabupaten Barito Utara dan Barito Selatan.

Gambar 8. Perbandingan Rasio PDRB tahun 2017-2019 dan Jumlah Perkembangan Jamaah Haji tahun 2017-2020 dibedakan menurut Kabupaten/Kota Provinsi Kalimantan Tengah

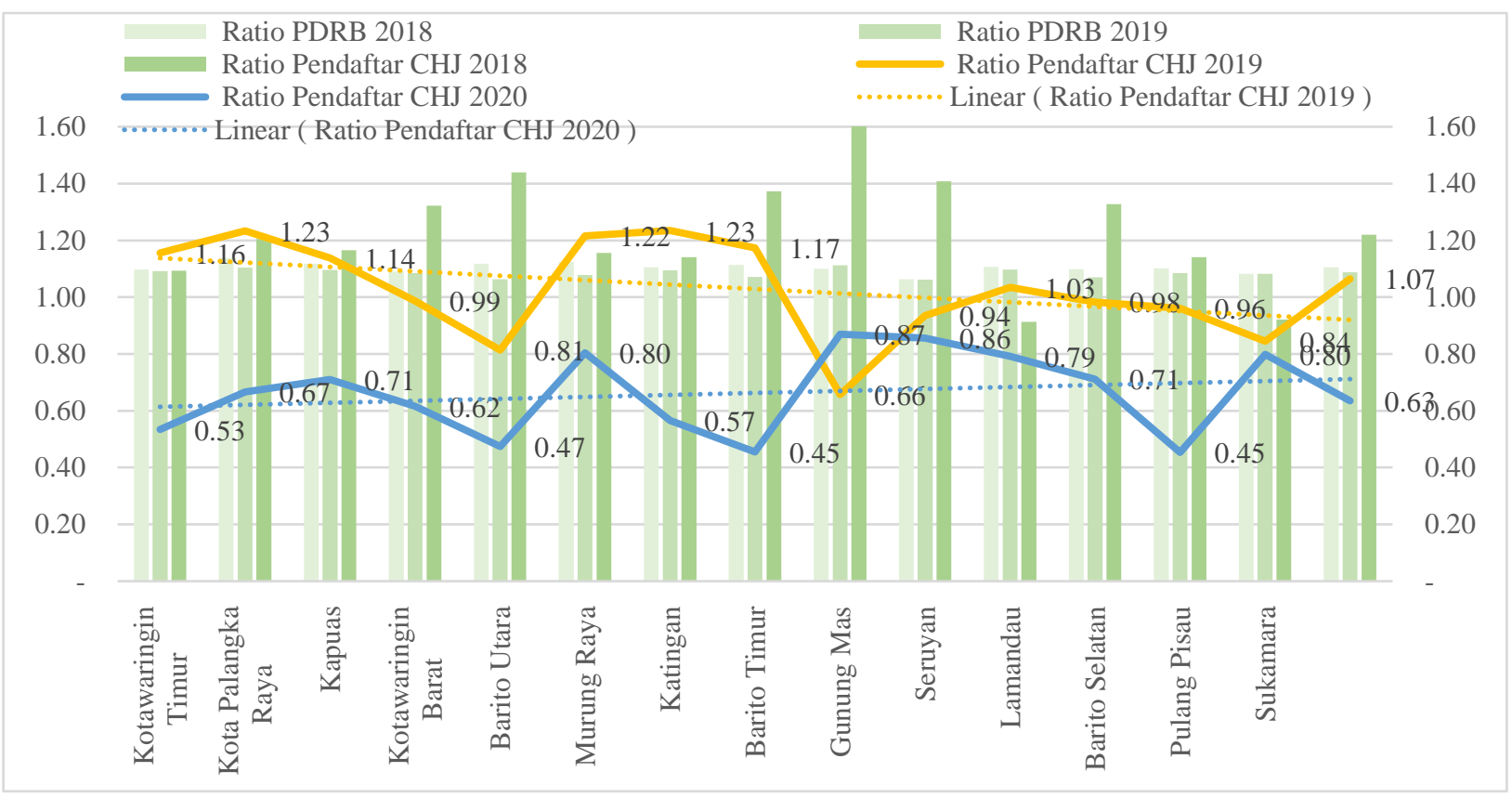

Sumber: Data Sekunder diolah, 2021.

Hasil uji koefisien korelasi dan regresi antara data PDRB tahun 2017-2019 dan pendaftar jamaah haji tahun 2017-2020 menunjukkan hasil koefisien korelasi positif dengan $\mathrm{r}^{2=0,8683}$ untuk pengujian tahun 2017, tahun 2018 menurun menjadi $\mathrm{r}^{2}=0,8425$, tahun 2019 meningkat dengan $r^{2}=0,8700$ dan tahun 2020 dengan $r^{2=0,7975}$. Nilai koefisien korelasi positif sangat kuat menunjukkan bahwa hubungan antara PDRB dan jumlah pendaftar jamaah haji searah, artinya peningkatan PDRB akan diikuti dengan peningkatan pendaftaran jamaah haji. Temuan penting ini sesuai dengan pendapat Tanjung (2010) yang mengatakan hikmah dari ibadah haji pada sistem produksi adalah tercipta peluang ekspor yang akan meningkatkan kekayaan negara, serta terhadap sistem distribusi yaitu dengan adanya ibadah haji akan tercipta distribusi kekayaan di tengah-tengah masyarakat yang dalam hal ini sama sama meningkatkan PDRB. 
Tabel 1. Hasil Uji Persamaan Regresi dan Koefisien Korelasi antara PDRB tahun 2017-2019 dan Jumlah Perkembangan Jamaah Haji tahun 2017-2020 Provinsi Kalimantan Tengah

\begin{tabular}{|c|c|c|l|c|c|}
\hline No & Tahun & Signifikansi (.Sig) & Persamaan Regresi & $\mathrm{R}$ & Koefisien Korelasi \\
\hline 1 & 2017 & 0,000056216180487801 & $\mathrm{y}=0,0333 \mathrm{x}-2,066$ & 0.7335 & 0,8683 \\
\hline 2 & 2018 & 0,000155490378223861 & $\mathrm{y}=0.03356 \mathrm{x}+9.097$ & 0.7098 & 0,8425 \\
\hline 3 & 2019 & 0,000052214453448519 & $\mathrm{y}=0.0384 \mathrm{x}-27.991$ & 0.7570 & 0,8700 \\
\hline 4 & 2020 & 0,000632129992556439 & $\mathrm{y}=0.0229 \mathrm{x}-1.723$ & 0,6361 & 0,7975 \\
\hline 5 & $\begin{array}{l}\text { Rerata } \\
2017-2019\end{array}$ & 0,000067729560890343 & $\mathrm{y}=0.0359 \mathrm{x}-6.817$ & 0,7464 & 0,8639 \\
\hline
\end{tabular}

Sumber: Data Sekunder diolah, 2021.

Temuan penting pada penelitian ini menunjukan bahwa hasil uji koefisien korelasi dan regresi antara data PDRB tahun 2017-2019 dan pendaftar jamaah haji tahun 2017-2020 menunjukkan hasil koefisien korelasi positif dengan $\mathrm{r}^{2=} 0,8683$ tahun 2017 berarti bahwa nilai PDRB telah menentukan banyaknya pendaftar jamaah haji di tahun 2017 sebesar 86,83\%, tahun 2018 sebesar 84,25\%, tahun 2019 sebesar 87,00\% dan tahun 2020 sebesar 79,75\%, sisanya ditentukan oleh faktor lain. Hal ini berarti bahwa besaran nilai PDRB di setiap kabupaten/kota telah sangat kuat menentukan jumlah pendaftar jamaah haji, semakin besar nilai PDRB di setiap kabupaten/kota maka semakin besar jumlah pendaftar jamaah haji dengan pengaruh yang sangat kuat.

\section{Analisis Kuadran Pengaruh Produk Domestik Regional Bruto Kabupaten/Kota terhadap Pendaftar Jamaah Haji Sebelum dan Selama Pandemi Covid-19}

Gambar 9 kuadran menunjukan bahwa jumlah pendaftar jamaah haji tinggi tahun 2019 (sebelum pandemi Covid-19) di Kabupaten Kotawaringin Timur, Kota Waringin Barat, Kota Palangka Raya dan Kapuas sangat terpengaruh oleh nilai PDRB kabupaten/kota tinggi. Di Kabupaten Barito Utara dan Barito Selatan jumlah pendaftar jamaah haji tinggi pada kabupaten/kota dengan PDRB rendah, temuan penting ini diduga karena faktor lain yang cukup dominan dan turut mempengaruhi selain nilai PDRB.

Kuadran 1 menunjukkan bahwa kabupaten/kota dengan jumlah pendaftar jamaah haji yang rendah dan nilai PDRB yang rendah, 8 Kabupaten/kota yang termasuk dalam kuadran 1 yaitu Kabupaten Barito Timur, Seruyan, Murung Raya, Katingan, Pulang Pisau, Lamandau, Sukamara dan Gunung Mas. Kuadran 2 menunjukkan bahwa kabupaten/kota dengan jumlah pendaftar jamaah haji yang tinggi dan nilai PDRB yang rendah, 2 Kabupaten/kota yang termasuk dalam kuadran 2 yaitu Kabupaten Barito Utara dan Barito Selatan. Kabupaten pada kuadran 2 ini perlu mendapat perhatian terutama dalam peningkatan nilai PDRB kabupaten. Kuadran 3 menunjukkan bahwa kabupaten/kota dengan jumlah pendaftar jamaah haji yang rendah dan nilai PDRB yang tinggi, tidak ada kabupaten yang berada pada kuadran 3 ini. Kuadran 4 menunjukkan bahwa kabupaten/kota dengan jumlah pendaftar jamaah haji yang tinggi dan nilai PDRB yang tinggi, 4 kabupaten/kota yang termasuk pada kuadran 4 yaitu Kabupaten Kotawaringin Timur, Kota Waringin Barat, Kota Palangka Raya dan Kapuas. 
Gambar 9. Hasil Analisis Kuadran Pengaruh PDRB Kabupaten/Kota terhadap Pendaftar Jamaah Haji Provinsi Kalimantan Tengah Tahun 2019

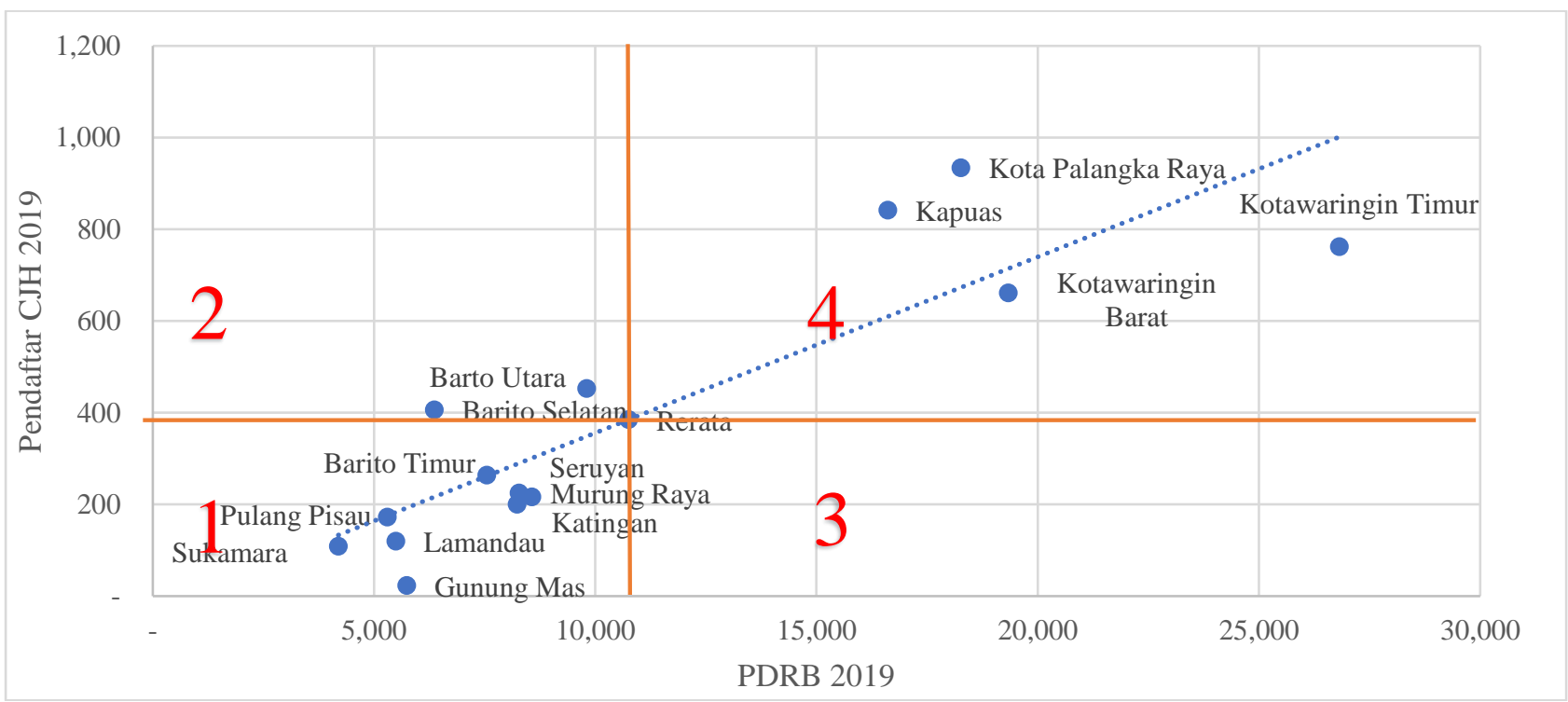

Sumber: Data Sekunder diolah, 2021.

Gambar 10 kuadran menunjukan bahwa jumlah pendaftar jamaah haji tinggi tahun 2020 (selama pandemi Covid-19) di Kabupaten Kotawaringin Timur, Kota Waringin Barat, Kota Palangka Raya dan Kapuas sangat terpengaruh oleh nilai PDRB kabupaten/kota tinggi. Di Kabupaten Barito Selatan jumlah pendaftar jamaah haji tinggi pada kabupaten/kota dengan PDRB rendah temuan penting ini diduga karena faktor lain yang cukup dominan dan turut mempengaruhi selain nilai PDRB.

Kuadran 1 menunjukkan bahwa kabupaten/kota dengan jumlah pendaftar jamaah haji yang rendah dan nilai PDRB yang rendah, 9 Kabupaten/kota yang termasuk dalam kuadran 1 yaitu Kabupaten Barito Utara, Barito Timur, Seruyan, Murung Raya, Katingan, Pulang Pisau, Lamandau, Sukamara dan Gunung Mas. Kuadran 2 menunjukkan bahwa kabupaten/kota dengan jumlah pendaftar jamaah haji yang tinggi dan nilai PDRB yang rendah, 1 Kabupaten/kota yang termasuk dalam kuadran 2 yaitu Kabupaten Barito Selatan. Kabupaten pada kuadran 2 ini perlu mendapat perhatian terutama dalam peningkatan nilai PDRB kabupaten. Kuadran 3 menunjukkan bahwa kabupaten/kota dengan jumlah pendaftar jamaah haji yang rendah dan nilai PDRB yang tinggi, tidak ada kabupaten yang berada pada kuadran 3 ini. Kuadran 4 menunjukkan bahwa kabupaten/kota dengan jumlah pendaftar jamaah haji yang tinggi dan nilai PDRB yang tinggi, 4 kabupaten/kota yang termasuk pada kuadran 4 yaitu Kabupaten Kotawaringin Timur, Kota Waringin Barat, Kota Palangka Raya dan Kapuas. Hal ini sesuai dengan hasil penelitian Warsilan dan Noor (2015); dan Aini (2019). 
Gambar 10. Hasil Analisis Kuadran Pengaruh PDRB Kabupaten/Kota terhadap Pendaftar Jamaah Haji Provinsi Kalimantan Tengah Tahun 2020

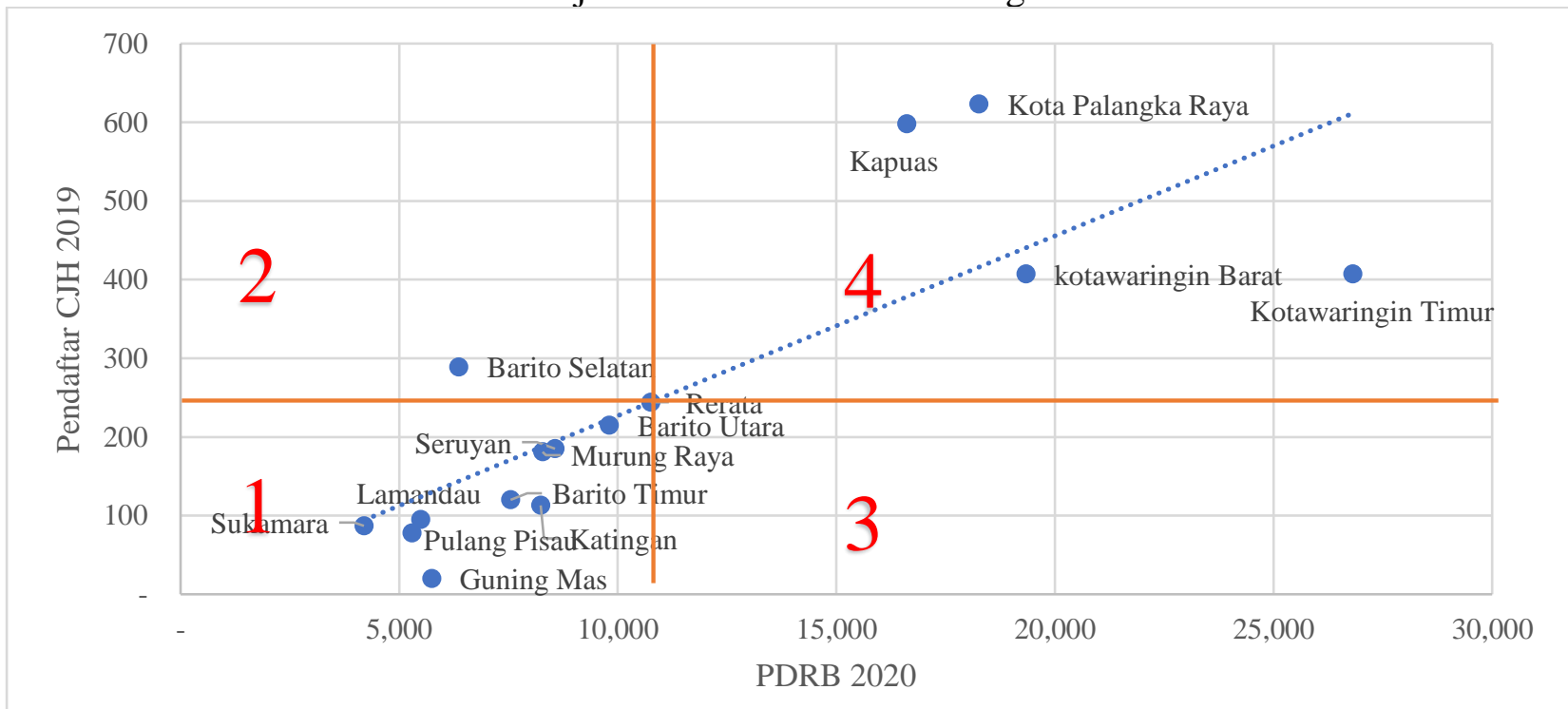

Sumber: Data Sekunder diolah, 2021.

\section{KESIMPULAN DAN SARAN}

\section{Kesimpulan}

1. Pandemi Covid-19 telah mempengaruhi jumlah pendaftar jamaah haji sebelum era Pandemi Covid-19 di tahun 2017-2019 yaitu rerata 347 orang dan selama Era Pandemi Covid-19 tahun 2020 hanya rerata 244 orang atau menurun sebesar $-33,52 \%$. Perkembangan PDRB selama 2017-2019 mengalami kenaikan secara rerata sebesar 19,81\%.

2. Peningkatan PDRB di setiap kabupaten/kota cenderung meningkatkan jumlah pendaftar jamaah haji sebelum maupun selama Pandemi Covid-19 di tahun 2017-2019 dan 2020. Analisis rasio di semua kabupaten/kota menunjukkan pola pertumbuhan PDRB tahun 2018 sebesar 1,11 menurun di tahun 2019 sebesar 1,09, kecuali Kabupaten Gunung Mas. Pola pertumbuhan jamaah haji tahun 2018 sebesar 1,22 menurun di tahun 2019 sebesar 1,07 dan sangat menurun di era pandemi Covid-19 di tahun 2020 sebesar 0,63, penurunan drastis di Kabupaten Barito Utara dan Barito Selatan.

3. PDRB telah mempengaruhi banyaknya pendaftar jamaah haji di tahun 2017 sebesar $86,83 \%$, tahun 2018 sebesar 84,25\%, tahun 2019 sebesar 87,00\% dan tahun 2020 sebesar $79,75 \%$, sisanya ditentukan oleh pengaruh faktor lain. Semakin besar PDRB di setiap kabupaten/kota maka semakin besar jumlah pendaftar jamaah haji dengan pengaruh yang sangat kuat.

4. Jumlah pendaftar jamaah haji tinggi tahun 2019 (sebelum pandemi Covid-19) di Kabupaten Kotawaringin Timur, Kota Waringin Barat, Kota Palangka Raya dan Kapuas sangat terpengaruh PDRB kabupaten/kota yang tinggi (kuadran 4). Di Kabupaten Barito Utara dan Barito Selatan jumlah pendaftar jamaah haji tinggi walaupun dengan PDRB rendah, hal ini diduga karena faktor lain yang cukup dominan dan turut mempengaruhi selain PDRB. Jumlah pendaftar jamaah haji tinggi tahun 2020 (selama pandemi Covid-19) di Kabupaten Kotawaringin Timur, Kota Waringin Barat, Kota Palangka Raya dan Kapuas sangat terpengaruh oleh PDRB kabupaten/kota tinggi (kuadran 4). Di Kabupaten Barito Selatan 
jumlah pendaftar jamaah haji tinggi walaupun PDRB rendah, hal ini diduga karena faktor lain yang cukup dominan dan turut mempengaruhi selain PDRB.

\section{Saran}

Kabupaten/kota yang berada pada kuadran 4 patut dijadikan sebagai best practice terutama bagi kabupaten/kota yang berada di kuadran 1 dalam peningkatan PDRB sehingga terjadi peningkatan pendaftar jamaah haji, pada kabupaten pada kuadran 2 perlu dilakukan penelitian lebih lanjut untuk mengetahui faktor yang mempengaruhi jumlah pendaftar jamaah haji selain PDRB.

\section{DAFTAR PUSTAKA}

Aini, L.M. (2019). Penentuan Provinsi-Provinsi Terbaik dalam Produksi Jagung Nasional melalui Analisis Kuadran Atas Variable Produksi dan Produktivitas per Satuan Luas Lahan. Jurnal Ekonomi Pertanian dan Agribisnis (JEPA). Vol. 3, No. 4 (2019), 751-760. https://doi.org/10.21776/ub.jepa.2019.003.04.10.

Badan Pusat Statistik (2020), Produk Domestik Regional Bruto Kabupaten/Kota di Indonesia 2015-2019. Jakarta: BPS RI, 180p.

Dong, Y., Mo, X., Hu, Y., Qi, X., Jiang, F., Jiang, Z., and Tong, S. (2020). Epidemiology of covid-19 among children in China. Pediatrics, 145(6),1-12. https://doi.org/10.1542/peds.2020-070.

Fitriani, 2013. Perhitungan dan Analisis Produk Domestik Regional Bruto (PDRB) Kabupaten/Kota Berdasarkan Harga Konstan (Studi Kasus BPS Kabupaten Kendal). Skripsi. Jurusan Statistika Fakultas Sains Dan Matematika Universitas Diponegoro. Semarang 2013.

Hadiwardoyo, W. (2020). Kerugian ekonomi nasional akibat pandemi covid-19. Baskara Journal of Business and Enterpreneurship, 2(2), 83-92. https://doi.org/10.24853/baskara.2.2.83-92

Halisa, N.N. dan Annisa, S. 2020). Pengaruh Covid-19, Nilai Tukar Rupiah dan Indeks Harga Saham Gabungan Asing Terhadap Indeks Harga Saham Gabungan Indonesia (IHSG). Jurnal Manajemen dan Organisasi (JMO), Vol. 11 No. 3, Desember 2020, 170-178.

Kirigia, J.M., and Muthuri, R.N.D.K. (2020). The fiscal value of human lives lost from coronavirus disease (COVID-19) in China. BMC Research Notes, 13(1), 1-5. https://doi.org/10.1186/ s13104-020-05044-y.

Romhadhoni, P., Faizah, D.Z. dan Afifah, N. (2018). Pengaruh Produk Domestik Regional Bruto (PDRB) Daerah Terhadap Pertumbuhan Ekonomi dan Tingkat Pengangguran Terbuka di Provinsi DKI Jakarta. Jurnal Matematika Integratif. Vol. 14, No. 2 (2018),115-121. doi:10.24198/jmi.v14.n2.2018.115-121.

Sahil, I. (2015). Pandangan Hukum Islam Tentang Arisan Haji. SYAIKHUNA: Jurnal Pendidikan dan Pranata Islam, Vol. 6 No. 2, Oktober 2015, 223-244.

Suhendra, A., dan Prasetyanto, D. W. I. (2016). Kajian Tingkat Kepuasan Pengguna Trans Metro Bandung Koridor 2 Menggunakan Pendekatan Importance-Performance Analysis. Rekaracana: Jurnal Online Institut Teknologi Nasional, 2(2), 1-12.

Suseno, D.A. dan Muhammad Azwar Anas, M.A. (2017). Multiplier Effect Sektor Basis Terhadap Perekonomian Daerah Provinsi Jawa Tengah. Jurnal Riset Ekonomi Pembangunan. Vol. 2 No. 2, April 2017, 113-125.

Tanjung, H. (2010), Hikmah Ibadah Hadi Terhadap Ekonomi, Bogor, Jurnal Ekonomi Islam Al-Infaq, Vol. 1 No. 1, September 2010, 6-20. 
Warsilan dan Noor, A. (2015). Peranan Infrastruktur terhadap Pertumbuhan Ekonomi dan Implikasi pada Kebijakan Pembangunan di Kota Samarinda. MIMBAR, Vol. 31, No. 2 (Desember, 2015), 359-366.

Weley, I.R., Kumenaung, A.G. dan Sumual, J.I. (2017). Analisis Pengaruh Inflasi dan Produk Domestik Regional Bruto (PDRB) terhadap Pendapatan Asli Daerah di Kota Manado. Jurnal Pembangunan Ekonomi dan Keuangan Daerah. Vol. 18, No. 6 (2017), 1-10.

Yang, J., Zheng, Y., Gou, X., Pu, K., Chen, Z., Guo, Q., Ji, R., Wang, H., Wang, Y., and Zhou, Y. (2020). Prevalence of comorbidities and its effects in coronavirus disease 2019 patients: A systematic review and meta-analysis. International Journal of Infectious Diseases, 94 (May), 91-95. https://doi.org/10.1016/j.ijid.2020.03.017

Yulianim, H., Sarbini, A. dan Herman, 2016, Implementasi Siskohat dalam Transparansi Informasi kepada Calon Jemaah Haji, Bandung, Tadbir: Jurnal Manajemen Dakwah. Vol. 1, No. 2, 2016, 102-112.

Zasriati, M, Hayuni, O. dan Wahyuni, I. (2020). Analisis Tingkat Pertumbuhan Ekonomi Dan Potensi Ekonomi Terhadap Produk Domestik Regional Bruto Kabupaten Kerinci Tahun 2008. Jurnal AKRAB JUARA. Vol. 5 No.1. Edisi Februari 2020, 188-195. 